\title{
Peningkatan Keterampilan Menulis Puisi Bebas Menggunakan Pendekatan Kontekstual Siswa Sekolah Dasar
}

\author{
Putri Hana Pebriana \\ Studi PGSD Fakultas Ilmu Pendidikan Universitas Pahlawan Tuanku Tambusai Riau \\ putripebriana99@gmail.com
}

\begin{abstract}
The purpose of this study is to describe the planning, implementation and results of free poetry writing skills in the Indonesian language class V SDN 004 Bangkinang with Contextual Approach. This research uses qualitative method of Type Class Action Research. Data obtained in the analysis using qualitative and quantitative data analysis. Stages of data analysis are described as follows: reviewing the data that has been collected either through observation, rectification, recording, or documentation, data reduction, presenting data and concluding the research results. The results of research after done on the cycle I skill of writing free poetry with a perspecage of 59.09\%. Then cycle II of free poetry writing skills has increased with the percentage of $86.36 \%$. Teacher activity in the first cycle of the first meeting of $65.71 \%$ and at the second meeting increased to $74.28 \%$. Then in cycle II the first meeting of teacher activity increased to $82.85 \%$ and at the second meeting increased to $88.57 \%$ ". Student activity on first cycle of the first meeting of $62.85 \%$ and at the second meeting increased to $68.57 \%$ with the category of "Good". Then in cycle II the first meeting of teacher activity increased to $77.14 \%$ and at the second meeting increased to $85.71 \%$. Thus it can be concluded that by using Contextual Approach Can Increase the Skill of writing poetry free Student Class V SDN 004 Bangkinang district Bangkinang City.
\end{abstract}

Keyword: Contextual Approach, Skill Writing, Free Poem

\section{PENDAHULUAN}

Pendidikan Bahasa Indonesia merupakan salah satu aspek penting yang perlu diajarkan kepada para siswa di sekolah. Maka mata pelajaran ini kemudian diberikan sejak masih bangku Sekolah Dasar (SD) karena dari situ diharapkan siswa mampu menguasai, memahami dan dapat mengimplementasikan keterampilan berbahasa. Seperti membaca, menyimak, menulis dan berbicara.

Permendiknas No. 22 Tahun 2006, Bahasa memiliki peran sentral dalam perkembangan intelektual, sosial, dan emosional peserta didik dan merupakan penunjang keberhasilan dalam mempelajari semua bidang studi. Pembelajaran bahasa diharapkan membantu peserta didik mengenal dirinya, budayanya, dan budaya orang lain, mengemukakan gagasan dan perasaan, berpartisipasi dalam masyarakat yang menggunakan bahasa tersebut, dan menemukan serta menggunakan kemampuan analitis dan imaginatif yang ada dalam dirinya. Pembelajaran Bahasa Indonesia diarahkan untuk meningkatkan kemampuan peserta didik dalam Bahasa Indonesia dengan baik dan benar.

Salah satu materi Bahasa Indonesia yang harus dikuasai siswa sekolah dasar (SD) adalah menulis puisi. Tarmizi (2013:12) menulis merupakan salah satu dari empat keterampilan berbahasa (mendengarkan, berbicara, membaca, dan menulis), menulis merupakan suatu proses bagaimana mengomunikasikan ide kepada orang lain dengan baik, sehingga orang lain dapat memahami apa yang disampaikan melalui tulisan. Sedangkan menurut Abidin (2014:19) menulis merupakan kegiatan yang ekspresif karena dengan menulis seseorang dapat mengungkapkan gagasan, maksud, pikiran, atau pesan yang dimilikinya kepada orang lain. Maka dapat disimpulkan menulis adalah suatu proses kegiatan yang dilakukan seseorang untuk mengungkapkan gagasan, pikiran dan mengkomunikasikan ide kepada orang lain dengan baik disamapikan melalui tulisan.

Franscatoro (Ganie, 2015:58) puisi adalah tiruan cita-cita atau ide-ide yang tersembunyi dalam kehidupan transcendental (dunia ilahi) atau dunia di luar pengalaman lahir manusia. 
Sedangkan menurut Tarmizi (2013:14) puisi adalah salah satu bentuk karya sastra yang tersaji secara monolog, menggunakan katakata yang indah dan kaya akan makna. Dapat disimpulkan bahwa puisi adalah salah satu bentuk karya sastra yang menggunakan katakata yang indah dan penuh dengan makna.

Berdasarkan observasi dan wawancara awal yang dilakukan dengan guru kelas $\mathrm{V}$ SDN 004 Bangkinang kecamatan Bangkinang Kota kabupaten Kampar, bahwa hasil belajar siswa khususnya pada mata pelajaran Bahasa Indonesia terutama menulis puisi masih belum sesuai dengan yang diharapkan. Dapat dilihat dari nilai rata-rata ulangan dengan KKM 75. Data awal jumlah siswa 31 orang, hanya 6 siswa ( $19,36 \%)$ yang tuntas, sedangakan 25 siswa ( $80,64 \%)$ mendapat nilai dibawah KKM. Maka dapat dikatakan bahwa dalam pembelajaran Bahasa Indonesia dengan materi menulis puisi di SDN 004 Bangkinang mengalami permasalahan. Adapun permasalahannya yaitu: (1) tidak adanya umpan balik antara guru dan siswa, (2) siswa tidak berani bertanya meskipun mengalami kesulitan saat proses pembelajaran, (3) guru begitu bingung bagaimana cara agar siswa mengerti cara menulis puisi, (4) siswa begitu kesulitan untuk mencari tema yang akan dituliskan, (5) siswa asyik bermain dan tidak memperhatikan penjelasan guru.

Permasalahan guru yang kesulitan untuk menyampaikan materi yang akan diajarkan membuat siswa tidak memahami materi yang diajarkan guru. Kondisi kelas yang tidak kondusif, siswa asyik bermain dan tidak mendengarkan penjelasan dari guru membuat suasana kelas menjadi ribut dan tidak tenang. Sikap siswa yang tidak mengerti dengan materi yang diajarkan guru, maka guru perlu strategi pembelajaran yang baru. Upaya yang dilakukan adalah melalui Pendekatan Kontekstual.

Johnson (dalam Rusman, 2014:187) mengatakan pembelajaran kontekstual adalah sebuah sistem yang merangsang otak untuk menyusun pola-pola yang mewujudkan makna. Johnson mengatakan bahwa pembelajaran kontekstual adalah suatu sistem pembelajaran yang cocok dengan otak yang menghasilkan makna dengan menghubungkan muatan akademis dengan konteks dari kehidupan sehari-hari siswa.

Taufik (2011:189) berpendapat bahwa pendekatan kontekstual adalah suatu model pembelajaran dimana guru harus menghadirkan situasi dunia nyata ke dalam kelas dan mendorong peserta didik membuat hubungan antara pengetahuan yang dimilikinya dengan menerapakannya dalam kehidupan mereka sebagai anggota keluarga dan masyarakat.

Untuk mengaitkannya bisa dilakukan berbagai cara, selain karena memang materi yang dipelajari secara langsung terkait dengan kondisi faktual, juga bisa disiasati dengan pemberian ilustrasi atau contoh, sumber belajar, media, dan lain sebagainya, yang memang baik secara langsung maupun tidak langsung maupun tidak diupayakan terkait atau ada hubungan dengan pengalaman hidup nyata. Maka pembelajaran selain akan lebih menarik, juga akan dirasakan sangat dibutuhkan oleh setiap siswa karena apa yang dipelajari dirasakan langsung manfaatnya (Rusman, 2014:187).

Maka dapat disimpulkan bahwa pembelajaran kontekstual adalah usaha untuk membuat siswa aktif dan memompa kemampuan diri tanpa merugi dari segi manfaat, serta merangsang otak siswa sehingga siswa berusaha mempelajari konsep sekaligus menerapkan dan mengkaitkannya dengan dunia nyata.

Pendidikan Bahasa Indonesia merupakan salah satu aspek penting yang perlu diajarkan kepada para siswa di sekolah. Maka mata pelajaran ini kemudian diberikan sejak masih bangku Sekolah Dasar (SD) karena dari situ diharapkan siswa mampu menguasai, memahami dan dapat mengimplementasikan keterampilan berbahasa. Seperti membaca, menyimak, menulis dan berbicara.

Permendiknas No. 22 Tahun 2006, Bahasa memiliki peran sentral dalam perkembangan intelektual, sosial, dan emosional peserta didik dan merupakan penunjang keberhasilan dalam mempelajari semua bidang studi. Pembelajaran bahasa diharapkan membantu peserta didik mengenal dirinya, budayanya, dan budaya orang lain, mengemukakan gagasan dan perasaan, berpartisipasi dalam masyarakat yang menggunakan bahasa tersebut, dan menemukan serta menggunakan kemampuan analitis dan imaginatif yang ada dalam dirinya. Pembelajaran Bahasa Indonesia diarahkan untuk meningkatkan kemampuan peserta didik dalam Bahasa Indonesia dengan baik dan benar.

Salah satu materi Bahasa Indonesia yang harus dikuasai siswa sekolah dasar (SD) adalah menulis puisi. Tarmizi (2013:12) menulis merupakan salah satu dari empat keterampilan 
berbahasa (mendengarkan, berbicara, membaca, dan menulis), menulis merupakan suatu proses bagaimana mengomunikasikan ide kepada orang lain dengan baik, sehingga orang lain dapat memahami apa yang disampaikan melalui tulisan. Sedangkan menurut Abidin (2014:19) menulis merupakan kegiatan yang ekspresif karena dengan menulis seseorang dapat mengungkapkan gagasan, maksud, pikiran, atau pesan yang dimilikinya kepada orang lain. Maka dapat disimpulkan menulis adalah suatu proses kegiatan yang dilakukan seseorang untuk mengungkapkan gagasan, pikiran dan mengkomunikasikan ide kepada orang lain dengan baik disamapikan melalui tulisan.

Franscatoro (Ganie, 2015:58) puisi adalah tiruan cita-cita atau ide-ide yang tersembunyi dalam kehidupan transcendental (dunia ilahi) atau dunia di luar pengalaman lahir manusia. Sedangkan menurut Tarmizi (2013:14) puisi adalah salah satu bentuk karya sastra yang tersaji secara monolog, menggunakan katakata yang indah dan kaya akan makna. Dapat disimpulkan bahwa puisi adalah salah satu bentuk karya sastra yang menggunakan katakata yang indah dan penuh dengan makna.

Berdasarkan observasi dan wawancara awal yang dilakukan dengan guru kelas $\mathrm{V}$ SDN 004 Bangkinang kecamatan Bangkinang Kota kabupaten Kampar, bahwa hasil belajar siswa khususnya pada mata pelajaran Bahasa Indonesia terutama menulis puisi masih belum sesuai dengan yang diharapkan. Dapat dilihat dari nilai rata-rata ulangan dengan KKM 75. Data awal jumlah siswa 31 orang, hanya 6 siswa ( $19,36 \%)$ yang tuntas, sedangakan 25 siswa ( $80,64 \%)$ mendapat nilai dibawah KKM. Maka dapat dikatakan bahwa dalam pembelajaran Bahasa Indonesia dengan materi menulis puisi di SDN 004 Bangkinang mengalami permasalahan. Adapun permasalahannya yaitu: (1) tidak adanya umpan balik antara guru dan siswa, (2) siswa tidak berani bertanya meskipun mengalami kesulitan saat proses pembelajaran, (3) guru begitu bingung bagaimana cara agar siswa mengerti cara menulis puisi, (4) siswa begitu kesulitan untuk mencari tema yang akan dituliskan, (5) siswa asyik bermain dan tidak memperhatikan penjelasan guru.

Permasalahan guru yang kesulitan untuk menyampaikan materi yang akan diajarkan membuat siswa tidak memahami materi yang diajarkan guru. Kondisi kelas yang tidak kondusif, siswa asyik bermain dan tidak mendengarkan penjelasan dari guru membuat suasana kelas menjadi ribut dan tidak tenang. Sikap siswa yang tidak mengerti dengan materi yang diajarkan guru, maka guru perlu strategi pembelajaran yang baru. Upaya yang dilakukan adalah melalui Pendekatan Kontekstual.

Johnson (dalam Rusman, 2014:187) mengatakan pembelajaran kontekstual adalah sebuah sistem yang merangsang otak untuk menyusun pola-pola yang mewujudkan makna. Johnson mengatakan bahwa pembelajaran kontekstual adalah suatu sistem pembelajaran yang cocok dengan otak yang menghasilkan makna dengan menghubungkan muatan akademis dengan konteks dari kehidupan sehari-hari siswa.

Taufik (2011:189) berpendapat bahwa pendekatan kontekstual adalah suatu model pembelajaran dimana guru harus menghadirkan situasi dunia nyata ke dalam kelas dan mendorong peserta didik membuat hubungan antara pengetahuan yang dimilikinya dengan menerapakannya dalam kehidupan mereka sebagai anggota keluarga dan masyarakat.

Untuk mengaitkannya bisa dilakukan berbagai cara, selain karena memang materi yang dipelajari secara langsung terkait dengan kondisi faktual, juga bisa disiasati dengan pemberian ilustrasi atau contoh, sumber belajar, media, dan lain sebagainya, yang memang baik secara langsung maupun tidak langsung maupun tidak diupayakan terkait atau ada hubungan dengan pengalaman hidup nyata. Maka pembelajaran selain akan lebih menarik, juga akan dirasakan sangat dibutuhkan oleh setiap siswa karena apa yang dipelajari dirasakan langsung manfaatnya (Rusman, 2014:187).

Maka dapat disimpulkan bahwa pembelajaran kontekstual adalah usaha untuk membuat siswa aktif dan memompa kemampuan diri tanpa merugi dari segi manfaat, serta merangsang otak siswa sehingga siswa berusaha mempelajari konsep sekaligus menerapkan dan mengkaitkannya dengan dunia nyata.

\section{METODE PENELITIAN}

Penelitian ini menggunakan metode kualitatif yang berjenis Penelitian Tindakan Kelas. Ebbut (dalam Kunandar, 2012:43) penelitian tindakan adalah kajian sistemik dari upaya perbaikan pelaksanaan praktik pendidikan oleh sekelompok guru dengan melakukan tindakan-tindakan dalam 
pembelajaran, berdasarkan refleksi mereka mengenai hasil dari tindakan-tindakan tersebut.

Subjek penelitian ini adalah semua siswa di kelas V SDN 004 Bangkinang dengan jumlah siswa 28 orang, 13 orang laki-laki dan 15 orang perempuan.Penelitian tindakan kelas ini dilaksanakan dua siklus. Siklus pertaman dilaksanakan dua kali pertemuan dan siklus kedua juga dua kali pertemuan. Alokasi waktu pada setiap pertemuan 70 menit. Pelaksanaan masing-masing siklus mengikuti tahap-tahap perencanaan, tindakan, observasi, dan refleksi.

Berhasil tidaknya penelitian dilakukan dapat diketahui dari data yang diperoleh. Terkait dengan itu, untuk memperoleh data dalam menjawab masalah penelitian dapat dilakukan dengan menggunakan instrumen penelitian yaitu sebuah alat bantu yang dipilih peneliti dalam kegiatan pengumpulan data, agar kegiatan tersebut berjalan dengan sistematis. Arikunto (dalam Sarjana, 2010:43). Data penelitian yang digunakan dalam penelitian tindakan kelas ini berupa observasi dan tes sebagai metode utama untuk memperoleh data.

Instrumen penelitian adalah alat atau fasilitas yang digunakan peneliti dalam mengumpulkan data agar pekerjaannya lebih mudah dan hasilnya lebih baik, dalam arti lebih cermat, lengkap dan sistematis sehingga lebih mudah diolah. Agar penelitian ini dapat dilaksanakan dengan baik maka perlu dipersiapkan instrument penelitian. Adapun instrumen penelitian yang perlu dipersiapkan sebagai berikut:

1. Perangkat pembelajaran

Perangkat pembelajaran yang digunakan pada penelitian ini sebagai berikut:

a. Silabus

Silabus merupakan penjabaran dari standar kompetensi dan kompetensi dasar yang bertujuan agar peneliti mempunyai acuan yang jelas dalam melakukan tindakan dan disusun berdasarkan prinsip yang berorientasi pada kompetensi. Berdasarkan prinsip tersebut, silabus meliputi: identitas, standar kompetensi, kompetensi dasar, materi pokok/pembelajaran, kegiatan pembelajaran, indikator, penilaian yang terdiri dari teknik, bentuk instrumen dan contoh instrument, serta alokasi waktu dan sumber belajar.

b. Rencana Pelaksanaan Pembelajaran (RPP)

Rencana pelaksanaan pembelajaran (RPP) adalah rencana yang menggambarkan prosedur dan pengorganisasian pembelajaran untuk mencapai satu kompetensi dasar yang ditetapkan dalam standar isi dan dijabarkan dalam silabus. Rencana pelaksanaan pembelajaran bertujuan agar peneliti mempunyai pedoman dalam pelaksanaan proses pembelajaran, yang disusun secara sistematis berisi: standar kompetensi, kompetensi dasar, indikator, tujuan pembelajaran, materi ajar model dan metode pembelajaran, langkah-langkah pembelajaran, sumber belajar, dan penilaian hasil belajar yang berpedoman kepada langkah-langkah penerapan pembelajaran pendekatan kontekstual.

\section{c. Lember kerja siswa (LKS)}

Lembar kerja siswa merupakan langkah kerja dalam mengkontruksikan konsep dengan prosedur yang dibuat sedemikian rupa sehingga siswa mampu menyelesaikan suatu permasalahan baik secara individu maupun kelompok.

\section{Instrumen pengumpulan data}

a. Tes

Metode tes dalam penelitian ini adalah cara memperoleh data yang berbentuk suatu tugas yang harus dikerjakan oleh siswa yang di tes (testee) dan dari tes tersebut akan diperoleh suatu skor. Setelah pelaksanaan pembelajaran maka dilaksanakan tes hasil belajar siswa kepada seluruh siswa. Tes yang diberikan berupa tes kemampuan siswa dalam menulis puisi bebas melalui pendekatan kontekstual. Adapun aspek yang dinilai dari hasil menulis puisi bebas adalah: (1) diksi (pilihan kata), (2) tema, (3) bahasa kias, (4) dan amanat.

\section{b. Observasi}

Observasi yang dilakukan penulis adalah pengamatan secara langsung pada saat berlangsungnya kegiatan proses belajar mengajar di kelas. Observasi dilaksanakan untuk mendapatkan data yang akurat mengenai pelaksanaan tindakan dan menjadi pedoman untuk melakukan tindakan selanjutnya. Dalam melakukan observasi ini, penulis duduk di belakang mencatat semua kejadiaan, baik yang dilakukan oleh guru maupun yang dilakukan oleh siswa yang bersangkutan di dalam kelas saat mengikuti proses belajar mengajar.

Analisis data diartikan sebagai upaya data yang sudah tersedia kemudian diolah dengan statistik dan dapat dugunakan untuk menjawab rumusan masalah dalam penelitian. Teknik analisis data dapat diartikan sebagai cara melaksanakan analisis terhadap data, dengan tujuan mengolah data tersebut untuk menjawab rumusan masalah. 
Data yang diperoleh di analisis dengan menggunakan analisis data kualitatif dan kuantitatif. Model data kualitatif oleh Miles dan Huberman (1992:16) yakni analisis data dimulai dengan menelaah sejak pengumpulan data sampai seluruh data terkumpul. Tahap analisi data diuraikan sebagai berikut:

1. Menelaah data yang telah terkumpul baik melalui observasi, pencacatan, perekaman, maupun dokumentasi. Kegiatan penelaahan ini diawali dengan transkripsi data hasil pengamatan, kemudian menganalisis, mensintesis, dan menyeimpulkan. Penelaahan ini dilakukan secara menyeluruh sejak awal data dikumpulkan hingga semua data terkumpul.

2. Reduksi data, meliputi pengkategorian dan mengklasifikasian. Semua data yang telah terkumpul diseleksi dan dikelompokkelompokkan sesuai dengan masalah penelitian. Yang telah diklasifikasikan tersebut kemudian diseleksi mana yang relevan dan mana yang tidak relevan. Data yang relevan selanjutnya dianalisis dan data yang tidak relevan dibuang.

3. Menyajikan data dilakukan dengan cara mengorganisasikan informasi yang telah direduksi. Data tersebut dipaparkan menurut jenisnya sesuai dengan masalah penelitian.

4. Menyimpulkan hasil penelitian. Kegiatan penyimpulan hasil penelitian dilakukan dengan menafsirkan makna sesuatu fenomena yang terjadi selama tindakan berlangsung.

\section{HASIL \& PEMBAHASAN}

\section{A. Deskripsi Pratindakan}

Sebelum dilakukan tindakan, peneliti melakukan observasi yaitu untuk mengetahui kemampuan siswa dalam menulis puisi bebas. Data dari observasi dan wawancara awal yang dilakukan dengan guru kelas V SDN 004 Bangkinang Kecamatan Bangkinang Kota Kabupaten Kampar, bahwa hasil belajar siswa khususnya pada mata pelajaran Bahasa Indonesia terutama menulis puisi masih belum sesuai dengan yang diharapkan. Dapat dilihat dari nilai rata-rata ulangan dengan KKM 75. Data awal jumlah siswa 31 orang, hanya 6 siswa ( $19,36 \%)$ yang tuntas, sedangakan 25 siswa ( $80,64 \%)$ mendapat nilai dibawah KKM.

\section{B. Deskripsi Hasil Tindakan Tiap Siklus}

Perbandingan hasil belajar siswa dari pratindakan, siklus I, dan siklus II pada materi menulis puisi bebas dengan menggunakan pendekatan kontekstual. Untuk mengetahui perekembangan hasil belajar siswa dari sebelum tindakan, siklus I dan II dengan menggunakan pendekatan kontekstual pada siswa kelas V SDN 004Bangkinang secara jelas dapat dilihat pada tabel berikut ini.

\section{Aktivitas guru}

Setelah dilakukan tindakan aktivitas guru meningkat dari $69,99 \%$ dengan kategori "Baik" karena berada pada rentang 61\% - 80\% pada siklus pertama, dan siklus II meningkat menjadi $85,71 \%$ dengan kategori "Baik sekali" karena berada pada rentang $81 \%-100 \%$.

Terdapat peningkatan pada aktivitas guru dalam proses belajar mengajar dengan menggunakan pendekatan kontekstual kelas V di SDN 004 Bangkinang. Pada siklus I dari pertemuan pertama dan kedua dengan persentase 69,99\% dengan kategori "Baik" dan meningkat pada siklus II dengan persentase 85,71\% dengan kategori "Baik sekali".

Dapat disimpulkan bahwa pada aktivitas guru meningkat pada siklus I pertemuan pertama dari $65,71 \%$ dengan kategori "Baik" dan pada pertemuan kedua meningkat menjadi $74,28 \%$ dengan kategori "Baik". Kemudian pada siklus II pertemuan pertama aktivitas guru meningkat menjadi $82,85 \%$ dengan kategori "Baik sekali" dan pada pertemuan kedua meningkat menjadi $88,57 \%$ dengan kategori "Baik sekali".

\section{Aktivitas Siswa}

Kemudian aktivitas siswa setelah dilakukan tindakan meningkat dari 65,71\% dengan kategori "Baik" karena berada pada rentang $61 \%$ - $80 \%$ pada siklus pertama, dan pada siklus II meningkat menjadi 79,92\% dengan kategori "Baik" karena berada pada rentang $61 \%$ - $80 \%$. Peningkatan pada aktivitas siswa dalam proses belajar mengajar dengan menggunakan pendekatan kontekstual kelas $\mathrm{V}$ di SDN 004 Bangkinang. Pada siklus I dari pertemuan pertama dan kedua dengan persentase $65,71 \%$ dengan kategori "Baik" dan meningkat pada siklus II dengan persentase 79,92\% dengan kategori "Baik".

Dapat disimpulkan bahwa pada aktivitas siswa meningkat pada siklus I pertemuan pertama dari $62,85 \%$ dengan kategori "Baik" dan pada pertemuan kedua meningkat menjadi $68,57 \%$ dengan kategori "Baik". Kemudian pada siklus II pertemuan pertama aktivitas 
guru meningkat menjadi $77,14 \%$ dengan kategori "Baik sekali" dan pada pertemuan kedua meningkat menjadi $85,71 \%$ dengan kategori "Baik sekali".

\section{Keterampiran Siswa Menulis Puisi Bebas}

Hasil keterampilan menulis puisi bebas dengan menggunakan pendekatan kontekstual kelas V di SDN 004 Bangkinang pada siklus I dan siklus II terdapatnya peningkatan pada keterampilan menulis puisi bebas dengan menggunakan pendekatan kontekstual kelas $\mathrm{V}$ di SDN 004 Bangkinang. Pada ulangan harian siklus I dengan persentase $59,09 \%$ dengan kategori "Cukup" dan meningkat pada siklus II dengan persentase 86,36\% dengan kategori "Baik sekali". Dapat disimpulkan bahwa pada keterampilan menulis puisi bebas siswa meningkat dari data awal sebelum tindakan keterampilan siswa dalam menulis puisi bebas 19,36\% dengan kategori "Kurang". Kemudian dilakukan tindakan dengan menggunakan pendekatan kontekstual pada siklus I keterampilan menulis puisi bebas siswa mencapai 59,09\% dengan kategori "Cukup" kemudian meningkat pada siklus II menjadi 86,36\% dengan kategori "Baik sekali".

Setelah melihat proses dan perubahan yang telah dipaparkan, peneliti hanya melakukan dua siklus. Karena sudah jelas hasil yang diperoleh pada tiap pertemuan mengalami peningkatan. Pada aktivitas guru siklus I pertemuan pertama masih banyak kekurangan dan pada pertemuan kedua guru mencoba untuk memperbaiki kesalahan dengan hasil yang cukup meningkat. Kemudian pada siklus II guru melakukan perubahan dengan hasil yang bagus dan pada pertemuan terakhir guru melakukannya dengan begitu baik sehingga hasil aktivitas guru meningkat pada tiap pertemuan.

Setelah itu aktivitas siswa kelas V SDN 004 Bangkinang juga mengalami peningkatan pada tiap pertemuannya. Siklus I pertemuan pertema aktivitas siswa saat proses belajar mengajar siswa masih bingung dengan langkah-langkah pembelajaran yang guru lakukan. Awalnya saat proses pembelajaran siswa tidak terbiasa dengan kelompok diskusi. Sehingga siswa masih bermain-main saat melakukan diskusi. Dan pada pertemuan keduanya siswa sudah mulai terbiasa dengan pembelajaran diskusi membuat mereka termotivasi untuk mengerjakan tugas bersamasama. Kemudian pada siklus II pertemuan pertama siswa mulai aktif dalam pembelajaran membuat aktivitas meningkat dari sebelumnya dan pada pertemuan terakhir aktivitas meningkat menjadi lebih baik dengan menggunakan pendekatan kontekstual.

Setelah itu hasil ulangan harian siswa menulis puisi bebas pada siklus I dan siklus II juga mengalami peningkatan. Pada siklus I kemampuan menulis puisi bebas siswa masih belum mencapai $85 \%$, dan dilakukan tindakan siklus II dengan hasil yang memuaskan meningkat dengan melebihi $85 \%$.

Sudah jelas hasil yang diperoleh dalam kemampuan menulis puisi bebas dengan menggunkan pendekatan kontekstual siswa kelas V SDN 004 Bangkinang kecamatan Bangkinang Kota Kabupaten Kampar. Dari hasil penelitian dan pembahasan yang telah diuraikan diatas, diketahui bahwa pendekatan kontektual dapat meningkatkan keterampilan menulis puisi. Johnson mengatakan bahwa pembelajaran kontekstual adalah suatu sistem pembelajaran yang cocok dengan otak yang menghasilkan makna dengan menghubungkan muatan akademis dengan konteks dari kehidupan sehari-hari siswa.

Taufik (2011:189) berpendapat bahwa pendekatan kontekstual adalah suatu model pembelajaran dimana guru harus menghadirkan situasi dunia nyata ke dalam kelas dan mendorong peserta didik membuat hubungan antara pengetahuan yang dimilikinya dengan menerapakannya dalam kehidupan mereka sebagai anggota keluarga dan masyarakat.

Berdasarkan hasil penelitian ini membuktikan bahwa hipotesis Jika diterapkan Pendekatan Kontekstual, maka hasil belajar Bahasa Indonesia materi Menulis Puisi "dapat meningkatkan keterampilan menulis puisi bebas Kelas V SD Negeri 004 Bangkinang Kecamatan Bangkinang Kota Kabupaten Kampar".

\section{KESIMPULAN \& SARAN}

Berdasarkan hasil analisis data, baik hasil data observasi aktivitas kegiatan guru dan siswa maupun hasil keterampilan menulis puisi siswa pada siklus I dan siklus II, hasil penelitian yang telah dijelaskan pada Bab IV, maka dapat diambil kesimpulan bahwa Siswa Kelas V SDN 004 Bangkinang Kecamatan Bangkinang Kota Kabupaten Kampar sebelum tindakan hanya mencapai persentase 19,36\% dengan kategori "Kurang sekali", karena berada pada rentang $0 \%$ - 20\%. Setelah dilakukan tindakan dengan menggunakan Pendekatan Kontekstual pada siklus I keterampilan menulis puisi bebas siswa 
meningkat dengan persantase 59,09\% dengan kategori "Cukup" karena berada pada rentang $41 \%-60 \%$. Setelah diperbaiki pada siklus II keterampilan menulis puisi bebas dengan menggunkan Pendekatan Kontekstual mengalami peningkatan yang cukup memuaskan dengan persentase $86,36 \%$ dengan kategori "Baik sekali" karena berada pada rentang $81 \%$ - 100\%. Artinya keterampilan siswa kelas V SD Negeri 004 Bangkinang Kabupaten Kampar dalam Menulis Puisi Bebas telah mencapai $85 \%$.

Aktivitas guru pada siklus I pertemuan pertama dari $65,71 \%$ dengan kategori "Baik" dan pada pertemuan kedua meningkat menjadi $74,28 \%$ dengan kategori "Baik". Kemudian pada siklus II pertemuan pertama aktivitas guru meningkat menjadi $82,85 \%$ dengan kategori "Baik sekali" dan pada pertemuan kedua meningkat menjadi $88,57 \%$ dengan kategori "Baik sekali".

Aktivitas siswa pada siklus I pertemuan pertama dari 62,85\% dengan kategori "Baik" dan pada pertemuan kedua meningkat menjadi $68,57 \%$ dengan kategori "Baik". Kemudian pada siklus II pertemuan pertama aktivitas guru meningkat menjadi $77,14 \%$ dengan kategori "Baik sekali" dan pada pertemuan kedua meningkat menjadi $85,71 \%$ dengan kategori "Baik sekali".

Dengan demikian dapat diambil kesimpulan bahwa dengan menggunakan Pendekatan Kontekstual dapat Meningkatkan Keterampilan Siswa Kelas V SDN 004 Bangkinang kecamatan Bangkinang Kota Kabupaten Kampar Dalam Menulis Puisi Bebas.

Berdasarkan hasil peneitian di atas, maka saran penulis yang berhubungan dengan penelitian ini adalah sebagai berikut:

1. Untuk meningkatkan kemampuan siswa dalam menulis puisi di sekolah diharapkan kepada Guru Bahasa Indonesia dan Sastra dapat menggunakan Pendekatan Kontekstual.

2. Untuk siswa agar lebih serius dalam pembelajaran tentang puisi.

3. Kepada peneliti selanjutnya agar meneliti lebih dalam pembelajaran tentang menulis puisi demi kesempurnaan peneliti selanjutnya.

4. Kepada kepala sekolah perlu memantau dan membina terhadap dampak kegiatan Penelitian Tindakan Kelas (PTK), sebagai bahan penilaian kemajuan yang telah dicapai, sehingga apa yang ditemukan pada
PTK dapat diimplementasikan dalam pelaksanaan pembelajaran di sekolah.

5. Kepada pengawas perlu mengadakan kunjungan supervise terhadap peneliti dalam pelaksanaan PTK sedang berlangsung, agar apa yang ditemukan dapat diimplementasikan pada proses pelaksanaan pembelajaran.

\section{DAFTAR PUSTAKA}

Abidin, R.D. (2014). Peningkatan Kemampuan Menulis Puisi Melalui Model Pembelajaran Kontekstual dengan Inspirator Gambar Peristiwa Pada Siswa Kelas VIIA SMP Albanna Denpasar. Universitas Mahasaraswati Denpasar: [Online] [Tersedia dalam: http://unmaslibrary.ac.id/wp

content/uploads/2014/11/peningkatankemampuan-menulis-puisi-melaluimodel-pembelajaran-kontektual-denganinspirator-gamba1.pdf [diakses 17 Maret 2016].

Ganie, T.N. (2015). Buku Induk Bahasa Indonesia. Banjarmasin: Araska.

Tarmizi. (2014). Peningkatan Menulis Puisi Siswa dengan Teknik Pemodelan di Kelas VIIID SMP Negeri 19 Kota Bengkulu. Universitas Bengkulu. [Online] [Tersedia dalam:

https://www.google.co.id/url?q=http://rep ository.unib.ac.id/8570/1/I,II,III,2-13tar.FI.pdf [diakses 17 Maret 2016].

Rusman. (2014). Model-Model Pembelajaran Mengembangkan Profesionalisme Guru (edisikedua). Jakarta: Rajawali Press.

Taufik Taufina, Muhammadi. (2011). Mozaik Pembelajaran Inovatif. Padang: Sukabina Press. 